\title{
ANALISA PENGARUH DIMENSI KUALITAS WEBSITE TERHADAP KEPUASAN DAN IMPLIKASINYA PADA LOYALITAS PELANGGAN (studi kasus pada www.Biznetnetworks.com)
}

\author{
Asep Afandi \\ Manajemen Informatika \\ AMIK Dian Cipta Cendikia Pringsewu \\ Jalan Jend. Ahmad Yani No. 134 Sidoharjo Pringsewu \\ E-mail : asepafandi189@gmail.com
}

\begin{abstract}
ABSTRAK
Perkembangan teknologi mengubah budaya pemasaran. Internet mendukung berbagai kegiatan bisnis secara global termasuk strategi penjualan global dari sebuah produk tidak terbatas pada waktu dan tempat. Calon pembeli hanya cukup dengan meng-klik sebuah halaman website untuk mendapatkan informasi tentang bandwich koneksi internet baik untuk perusahaan, perumahan dan perorangan.
\end{abstract}

Penelitian ini akan mengukur seberapa besar pengaruh website www.Biznetnetworks.com sebagai alat bantu informasi profil perusahaan dan pemasaran produk jasa koneksi internet oleh perusahaan Biznet. Dengan mengetahui seberapa besar pengaruh $e$-Servqual terhadap tingkat kepuasan dan besar pengaruh kepuasan pelanggan terhadap loyalitas mereka. Hasil yang diperoleh menunjukkan bahwa 5 variabel $e$ Servqual yang mempengaruhi variabel Kepuasan pengguna website, dengan korelasi tinggi pada tiap variabel terhadap Kepuasan Pada Dimensi 1 (D1) dengan Kepuasan (K) berkorelasi dengan nilai 0,651. Pada Dimensi 2 (D2) dengan Kepuasan (K) dengan nilai 0,634. Pada Dimensi 3 (D3) dengan Kepuasan pada nilai 0,708. Pada Dimensi 4 (D4) dengan variable Kepuasan (K) pada nilai 0,777. Dan variabel Dimensi 5 (D5) dengan Kepuasan (K) pada nilai 0,767. Nilai signifikansi yang ditampilkan menunjukkan bahwa hubungan diantara kedua variabel perhitungan pada tiap dimensi memiliki signifikansi yang hampir kesemuanya cukup baik, sehingga regresi ini layak untuk dilakukan. Dan pengaruh 5 variabel dimensi tersebut berpengaruh pada variabel kepuasan sebesar 72,. Pada ANOVA, nilai F menunjukkan angka 6,210 dan Significance F memperlihatkan signifikansi yang berada diatas batas 0,05; yaitu 1,054. Maka, regresi ini tidak layak dilakukan.

Kemudian, pada perhitungan pengaruh variabel Kepuasan terhadap variabel Loyalitas pelanggan maka akan didapatkan Pada gambar tabel ANOVA, nilai F adalah 114,8086 dengan signifikansi sebesar 5,44. Ini berarti regresi yang dilakukan layak untuk dipakai. Hasil penelitian yang didapatkan dapat dijadikan tolak ukur pengambilan keputusan terhadap ke-efektifan penggunaan website sebagai media pemasaran produk dan optimalisasi penggunaannya.

Kata kunci : e-Servqual, Regresi Linier Berganda, Regresi Linier Sederhana, Kepuasan, Loyalitas

\section{PENDAHULUAN}

\subsection{Latar Belakang}

Perkembangan teknologi mengubah budaya pemasaran. Internet mendukung berbagai kegiatan bisnis secara global termasuk strategi penjualan global dari sebuah produk tidak terbatas pada waktu dan tempat. Calon pembeli hanya cukup dengan meng-klik sebuah halaman website untuk mendapatkan informasi tentang bandwich koneksi internet baik untuk perusahaan, perumahan dan perorangan. Penelitian ini akan mengukur seberapa besar pengaruh website www. Biznetnetworks.com sebagai alat bantu informasi profil perusahaan dan pemasaran produk jasa koneksi internet oleh perusahaan Biznet. Dengan mengetahui seberapa besar pengaruh e-Servqual terhadap tingkat kepuasan dan besar pengaruh kepuasan pelanggan terhadap loyalitas mereka 


\subsection{Tujuan Penelitian}

1. Untuk menganalisa responden dari pelanggan terhadap kwalitas web www. Biznetnetworks.com

2. Untuk menganalisa berapa besar kepuasan responden terhadap web www.Bisnetnetworks.com

3. untuk menganalisa berapa besar kesetiaan atau loyalitas responden terhadap web www.Bisnetnetworks.com

\subsection{Manfaat Penelitian}

Secara umum terdapat dua buah manfaat yang diharapkan dari penelitian ini, antara lain:

1. Hasil penelitian yang didapatkan dijadikan tolak ukur pengambilan keputusan terhadap ke-efektifan penggunaan website sebagai media pemasaran produk dan optimalisasi penggunaannya.

2. Dengan penelitian ini dapat diketahui berapa besar kesetiaan atau loyalitas responden terhadap web www.Bisnetnetworks.com

\section{TINJAUAN PUSTAKA}

\subsection{Perusahaan : Definisi Dan Tujuan}

\subsubsection{Definisi Perusahaan}

Perusahaan merupakan badan usaha yang menjalankan kegiatan di bidang perekonomian ( keuangan, industri, dan perdagangan), yang dilakukan secara terus menerus atau teratur ( regelmatig) terang-terangan (openlijk), dan dengan tujuan memperoleh keuntungan dan/ atau laba (Abdul R Saliman, SH, MM, dkk, "Hukum Bisnis Untuk Perusahaan (Teori dan Contoh Kasus)", Kencana Renada Media Group, Jakarta 2005. Hal. 100, dikutip dari : http://repository.usu.ac.id )

Dalam Pasal 1 huruf (b) UU Nomor 3 Tahun 1982 tentang Wajib Daftar Perusahaan dijelaskan bahwa perusahaan adalah setiap bentuk usaha yang menjalankan setiap jenis usaha yang bersifat tetap dan terus menerus dan yang didirikan, bekerja serta berkedudukan dalam wilayah Republik Indonesia, untuk tujuan memperoleh keuntungan dan atau laba.

\subsubsection{Tujuan Perusahaan Dan Cara Pencapaiannya}

Perusahaan secara keseluruhan, baik skala kecil maupun besar sesungguhnya memiliki tujuan primer yang sama, yaitu menghasilkan laba, meningkatkan kesejahteraan pemilik perusahaan, manajemen dan karyawan, berkesinambungan, bertumbuh, dan menyediakan produk spesifik untuk menjawab kebutuhan tertentu masyarakat. Sejalan dengan hal tersebut. Levy dan Sarnat (1990:2) merinci tujuan perusahaan menjadi delapan macam yaitu:

1. Memaksimalkan laba

2. Memaksimalkan penjualan

3. Mempertahankan eksistensi perusahaan

4. Mencapai tingkat laba yang memuaskan

5. Mencapai pangsa pasar tertentu

6. Meminimalkan karyawan yang meninggalkan perusahaan

7. Kedamaian internal (adanya pertentangan diantara jajaran manajemen)

8. Memaksimalkan kesejahteraan manajemen

Tanpa mengurangi maksud dan tujuan perusahaan yang telah dikemukakan di atas, pada dasarnya tujuan umum perusahaan dibagi menjadi:

1. Tujuan memaksimumkan laba

2. Tujuan memaksimumkan perusahaan

nilai

\subsection{Peran Pemasaran Dalam Perusahaan}

2.2.1. Pemasaran Dan Manajemen Pemasaran Ada beberapa definisi mengenai pemasaran diantaranya adalah :

a. Philip Kotler (Marketing) pemasaran adalah kegiatan manusia yang diarahkan untuk memenuhi kebutuhan dan keinginan melalui proses pertukaran.

b. Menurut Philip Kotler dan Amstrong pemasaran adalah sebagai suatu proses sosial dan managerial yang membuat individu dan kelompok memperoleh apa yang mereka butuhkan dan inginkan lewat penciptaan dan pertukaran timbal balik produk dan nilai dengan orang lain.

c. Pemasaran adalah suatu sistem total dari kegiatan bisnis yang dirancang untuk merencanakan, menentukan harga, promosi dan mendistribusikan barangbarang yang dapat memuaskan keinginan dan mencapai pasar sasaran serta tujuan perusahaan.

d. Menurut W Stanton pemasaran adalah sistem keseluruhan dari kegiatan usaha yang ditujukan untuk merencanakan, menentukan harga, mempromosikan dan mendistribusikan barang dan jasa yang dapat memuaskan kebutuhan pembeli maupun pembeli potensial.

Sedangkan, Manajemen pemasaran berasal dari dua kata yaitu manajemen dan pemasaran. Menurut Kotler dan Armstrong pemasaran 
adalah analisis, perencanaan, implementasi, dan pengendalian dari program-program yang dirancang untuk menciptakan, membangun, dan memelihara pertukaran yang menguntungkan dengan pembeli sasaran untuk mencapai tujuan perusahaan. Sedangakan manajemen adalah proses perencanaan (Planning), pengorganisasian (organizing) penggerakan (Actuating) dan pengawasan.

Jadi dapat diartikan bahwa Manajemen Pemasaran adalah sebagai analisis, perencanaan, penerapan, dan pengendalian program yang dirancang untuk menciptakan, membangun, dan mempertahankan pertukaran yang menguntungkan dengan pasar sasaran dengan maksud untuk mencapai tujuan - tujuan organisasi.

Strategi - strategi yang terdapat dalam manajemen pemasaran terbagi menjadi sembilan strategi, yaitu :

$\checkmark$ Strategi kepuasan pelanggan

$\checkmark$ Strategi pasar

$\checkmark$ Strategi produk

$\checkmark$ Strategi penetapan harga

$\checkmark$ Strategi distribusi

$\checkmark$ Strategi promosi

$\checkmark$ Strategi pemasaran dalam produk life cycle

$\checkmark$ Strategi pemasaran dalam posisi persaingan

$\checkmark$ Strategi pemasaran internasional

\subsubsection{Manajemen Pemasaran Dan Tujuan \\ Perusahaan}

Manajemen Pemasaran adalah suatu proses analisis, perencanaan, implementasi, koordinasi dan pengendalian program pemasaran yang meliputi kebijakan produk, harga, promosi, dan distribusi dari produk, jasa, dan ide yang ditawarkan untuk menciptakan dan meningkatkan pertukaran manfaat dengan pasar sasaran dalam upaya pencapaian tujuan organisasi (Boyd, Walker, Larreche, 1998, p.16).

Manajer pemasaran dalam melakukan aktifitasnya perlu memikirkan orientasi atau filosofi yang mendasari upaya pemasarannya. Melalui filosofi tersebut kegiatan pemasaran mempunyai pola orientasi bisnis dan pemasaran baik pada perusahaan, pelanggan ataupun masyarakat.

Terdapat lima konsep sebagai bentuk filosofi dalam pemasaran yaitu :

1. Konsep produksi yaitu konsep yang berorientasi produksi menekankan bahwa kegiatan produksi harus diutamakan dan dilakukan sebanyak-banyaknya untuk memenuhi permintaan. Tujuan konsep produksi adalah pencapaian efisiensi prosuksi, biaya rendah, dan distribusi massa.

2. Konsep produk yaitu konsep yang menekankan bahwa sukses pemasaran tergantung pada kualitas produk yang dihasilkan perusahaan. Perusahaan yang memakai konsep ini selalu berusaha memenangkan persaingan melalui pembuatan produk unggulan Perusahaan selalu berupaya menghasilkan produk berkulitas dan terus memperbaiki dan meningkatkan kualitas produknya.

3. Konsep penjualan yang menekankan bahwa konsumen tidak akan mengkonsumsi produk dari suatu perusahaan, apabila perusahaan tersebut tidak melakukan usaha promosi dan penjualan yang agresif.

4. Konsep pemasaran merupakan konsep yang lebih menitikberatkan pada kepentingan pelanggan atau kepuasan konsumen. Filosofi konsep pemasaran dikemukakan oleh Kotler sebagai berikut:

Konsep pemasaran sebagai filosofi berpendapat bahwa kunci untuk mencapai tujuan organisasi terdiri dari penentuan kebutuhan dan keinginan pasar sasaran serta memberikan kepuasan yang diinginkan secara lebih efektif dan efisien dibanding pesaingnya.

Dengan demikian konsep pemasaran sebagai

filosofi mencakup tiga unsur, yaitu:

1. Orientasi pelanggan. Orientasi pelanggan terdiri dari kegiatan penentuan produk dan program pemasarannya melalui pengembangan dan implementasi strategi pemasaran.

2. Pemasaran yang terkoordinasi dan terintegrasi. Perlunya koordinasi dan integrasi seluruh kegiatan pemasaran pada berbagai unit di dalam perusahaan ditujukan untuk dapat memberikan kepuasan pelanggan.

3. Pencapaian tujuan kinerja organisasi. Tujuan perusahaan adalah untuk mendapatkan laba atau tingkat keuntungan yang layak yang dapat digunakan untuk mengembangkan perusahaan.

Kesimpulannya, pemasaran sendiri merupakan elemen penting dalam sebuah perusahaan, penjualan barang merupakan salah satu cara agar perusahaan mendapatkan laba. Sehingga untuk mengatur pengendalian biaya produksi, 
distribusi dan lainnya, pemasaran harus diatur dengan baik.

\subsection{Pemasaran Berbasis Web \\ 2.3.1. Definisi}

Pemasaran berbasis Web disebut juga $e$ Marketing, didefinisikan oleh Dave Chaffey adalah menerapkan teknologi yang membentuk saluran online (Web, e-mail, database, mobile/wireless dan digital TV) untuk member kontribusi pada aktivitas pemasaran yang ditujukan untuk mencapai akuisisi yang menguntungkan dan pemeliharaan pelanggan (di dalam sebuah proses pembelian multichannel dan dayr hidup pelanggan) melalui peningkatan pengetahuan pelanggan (profil, perilaku, nilai dan pendorong loyalitas mereka), kemudian mengirimkan komunikasi bersasaran terintergrasi dan layanan-layanan online dengan kebutuhan mereka.

\subsubsection{Kelebihan Pemasaran Berbasis Web}

Menurut Kotler (2003, pp2-4), revolusi digital telah menempatkan sekumpulan kemampuan baru kepada konsumen dan bisnis. Beberapa hal yang dimiliki konsumen dewasa ini yang tidak dimiliki dahulu:

$\checkmark$ Peningkatan dalam daya beli yang signifikan. Pembeli dapat dengan mudah membandingkan harga dan atribut produk pesaing dan memperoleh jawaban hanya dalam hitungan detik.

$\checkmark$ Ketersediaan antara barang dan layanan yang lebih variatif. Sekarang orang dapat memesan hamper apa saja dari internet dan memesan darimana saja.

$\checkmark$ Ketersediaan sejumlah besar informasi mengenai hamper segala hal. Orang dapat membaca hamper semua surat kabar apapun dalam bahasa apapun, dan dari mana saja.

$\checkmark$ Kemudahan dalam berinteraksi serta menempatkan dan menerima pesan dari rumah, kantor, taua telepon seluler 24 jam sehari, 7 hari seminggu dan pesan tersebut akan dikirimkan ke rumah atau kantor mereka dengan cepat.

$\checkmark$ Kemampuan membandingkan catatan dan produk tentang jasa layanan. Sekarang pembeli dapat masuk ke dalam chat room dengan kepentingan yang sama dan bertukar informasi dan opini.

Teknologi Informasi dalam era digital juga telah memberikan perusahaan kemampuan: $\checkmark$ Menjalankan saluran informasi dan penjualan baru yang kuat dengan jangkauan geografis yang meluas untuk menginformasikan dan mempromosikan bisnis dan produk

$\checkmark$ Mengumpulkan informasi yang lebih lengkap dan penuh tentang pasar, pelanggan, prospek, dan pesaing, serta dapat melakukan riset pemasaran terbaru menggunakan internet

$\checkmark$ Memfasilitasi dan mempercepat komunikasi internal diantara para karyawan

$\checkmark$ Berkomunikasi secara dua arah dengan pelanggan dan prospek, dan bertransaksi dengan lebih efisien. Internet memudahkan setiap individu untuk mengirimkan pesan e-mail kepada perusahaan dan menerima balasan, dan banyak perusahaan sekarang mengembangkan ekstranet dengan pemasok dan distributor untuk mengirim danmenerima informasi, menempatkan pesanan dan melakukan pembayaran secara lebih efisien

$\checkmark$ Mengirim iklan, kupon, sampel dan informasi kepada pelanggan yang telah memintanya atau yang telah mengijinkan perusahaan untuk mengirim hal-hal tersebut

$\checkmark$ Membuat penawaran dan layanan untuk pelanggan secara individual melalui informasi tentang kunjungan pelanggan yang terkumpul dan disimpan dalam basis data perusahaan

$\checkmark$ Memerbaiki proses pembelian, peneriamaan karyawan, pelatihan serta komunikasi internal dan eksternal

$\checkmark$ Meningktkan efisiensi proses logistic dan operasional sekaligus meningkatkan akurasi dan kualitas layanan.

\section{4. e-SERVQUAL}

E-Servqual menurut Parasuraman dkk (2005:8) yang terdiri dari E-QUAL (e-core service quality) dan E-RecS-QUAL (e-recovery service quality), yang terdiri atas:

1. Efisiensi (efficiency) : Kemudahan dan kecepatan dalam mengakses dan menggunakan situs, kemampuan dari pelanggan untuk, mendapatkan website, dimana untuk menemukan produk yang diinginkan dan informasi yang berhubungan dengan produk tersebut, dan mencari kebenarannya dengan sedikit usaha. 
2. Kehandalan (Reliability): fungsi koreksi teknikal dari situs. Berhubungan dengan fungsional tehnik dari situs, terutama bagian bagian dari situs yang tersedia dan dapat berfungsi dengan baik

3. Privasi (privacy): tingkat dimana situs aman dan melindungi informasi pelanggan. Jaminan data perilaku berbelanja pelanggan yang tidak dibagikan serta informasi dari kartu kredit pelanggan yang aman terjaga.

4. Ketanggapan (responsiveness): efektifitas dalam mengatasi masalah dan mengembalikan melalui situs.

5. Kontak (contact): ketersediaan dalam membantu melalui telepon atau secara online. Pelanggan dapat melakukan kontak langsung melalui media telepon atau media online lainnya yang disediakan. Variabel pemenuhan (fulfillment) dan variabel kompensasi (compensation) tidak disertakan dalam penelitian ini karena 2 variabel tersebut dirasa tidak cocok untuk meneliti objek yang ada.

\section{METODE PENELITIAN \\ 3.1. Objek Penelitian}

Identitas Objek Penelitian :

Biznet Networks berdiri pada tahun

1. Nama BIZNET

Perusahaan:

2. Bidang Perusahaan yang fokus di Usaha: bisnis telekomunikasi \& multimedia

3. Alamat: Midplaza II Lantai 8, Jl. Jendral Sudirman Kav.1011. Tanah Abang, Jakarta Pusat

4. Website: www.Biznetnetworks.com 2000 sebagai Internet Provider Service yang menyediakan kebutuhan Internet untuk pelanggan bisnis. Pada tahun 2000, Biznet menggunakan teknologi Wireless dan InBuilding Ethernet. Berkat dukungan dari tim teknis terbaik dan penuh komitmen, Biznet Networks mulai merintis jalan untuk menjadi salah satu Network Service Provider terdepan di Indonesia

Munculnya kebutuhan akan infrakstrutur jaringan yang andal membuat Biznet Networks paham bahwa banyak perusahaan tergantung pada keandalan infrakstruktur untuk bisnis mereka. Lewat penelitian dan pengembangan, tim Biznet Networks Engineering Labs menganggap bahwa serat optik adalah jaringan terbaik dan tak lama setelah itu mulai merentang kabel serat optik di seputar Jakarta

\subsection{Jenis Dan Teknik Pengumpulan Data}

3.2.1. Jenis Data

Jenis data yang digunakan adalah data primer dan data sekunder. Data primer berasal dari angket (kuesioner) dan data sekunder berasal dari buku dan kutip tidak langsung melalui website perusahaan yang dianalisa.

\subsubsection{Teknik Pengumpulan Data}

Pengumpulan data dilakukan dengan memakai angket, lembar angket secara manual, menggunakan kuisioner yg dibagikan kepada responden untuk mengisi penilaian terhadap web:www.Biznetnetwork.com, penilaian terbagi dalam tiga kategori yaitu:Kwalitas web,kepuasan terhadap layanan yang terdapat dalam web dan kesetian pelanggan terhadap web.

\subsection{Metode Analisis Data}

Metode yang digunakan dalam menganalisis data adalah metode Regresi Linier Berganda dan metode. Metode perhitungan tersebut dapat dilihat dari gambar berikut:

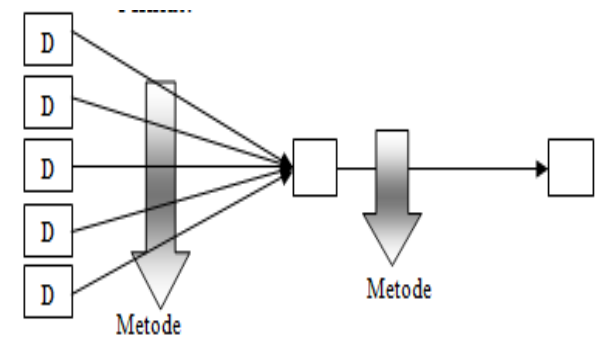

Gambar 1. Metode Analisa

Dengan melihat keterhubungan antara 5 variabel Dimensi Kualitas Website (D1, D2, D3, D4 dan D5) dengan variabel Keputusan (K) maka digunakan metode Regresi Linier Berganda dan Regresi Linier Sederhana digunakan untuk meihat keterhubungan antara variabel Kepuasan (K) dengan variabel Loyalitas (L).

Maka dapat dijelaskan bahwa, pada Regresi Linier Berganda untuk variabel D1, D2, D3, D4 dan D5 adalah variabel independen dari variabel dependen K. Dan variabel Kepuasan merupakan 
variabel independen dari variabel $\mathrm{L}$ yang dependen. Variabel independen merupakan variabel bebas yang tidak bergantung pada variabel apapun. Sedangkan variabel dependen merupakan variabel yang bergantung pada variabel lainnya.

\section{HASIL DAN PEMBAHASAN}

\subsection{Profil Perusahaan}

4.1.1. Sejarah/ Profil Singkat

Misi

Biznet adalah perusahaan yang fokus di bisnis telekomunikasi dan multimedia. Biznet memiliki komitmen untuk membangun infrastruktur telekomunikasi \& multimedia modern untuk menunjang penduduk Indonesia, bisnis dan pendidikan.Biznet akan menyediakan layanan dan teknologi muktahir kepada penduduk Indonesia untuk mengurangi kesenjangan digital dengan negara berkembang lainnya.

Visi

Menjadi penyelenggara telekomunikasi \& multimedia terkemuka di Indonesia dengan memberikan jaringan dengan kemampuan tinggi, customer care yang ramah dan inovasi layanan dengan menggunakan teknologi terkini.

\section{Profil Perusahaan :}

\section{Nama Perusahaan:BIZNET}

2.Bidang Usaha:Perusahaan yang fokus di bisnis telekomunikasi \& multimedia 3.Alamat:Midplaza II Lantai 8, Jl. Jendral Sudirman Kav.10-11 . Tanah Abang, Jakarta Pusat

4.Website:www.Biznetnetworks.com

Perusahaan ini berusaha untuk selalu mengedepankan kualitas melakukan segala upaya untuk membuat klien puas dan memiliki kenangan yang baik di Indonesia. Website www.Biznetnetworks.com digunakan untuk menampilkan produk yang ditawarkan. Jenis media koneksi yang digunakan semuanya berbasis Fiber optic, kelebihannya adalah kecepatan dan kestabilan coneksi.

4.1.2.Komoditas (Barang/Jasa) Yang Ditawarkan Produk :

1. Metronet: internet prabayar, system koneksinya menggunakan dial PPPoE dengan user name dan password yang diberikan oleh biznet, Unlimited dengan speed dari 1 mbps samapai 20 mbps koneksi internasionalnya bersifat share.
2. Max3 : internet prabayar, system koneksinya sama dengan metronet, namun Max3 ini ada untuk perumahan, bukan untuk perkantoran, koneksi internasionalnya bersifat share apabila infrastruktus ada TV nya, maka langganan internetnya bonus TV.

3. Dedicated Line : internet pasca bayar, system koneksinya menggunakan ststic IP, koneksi internasionalnya bersifat tetap, ada garansinya misalnya: langganan $10 \mathrm{mbps}$, maka bandwithnya dijamin tetap 10 mbps.

4. Cloud Computing : ini seperti kita sewa perangkat computer, namun komputernya ada disservernya biznet dan sifatnya virtual,apabila anda menyewa cloud computing ini maka anda juga sudah mendapatkan bandeith internetnya.

\subsection{Karakteristik Responden}

4.2.1. Kelompok Responden Berdasarkan Usia Kelompok usia dari 80 responden adalah berkisar pada 18 - 52 tahun. Penjelasan ada pada tabel berikut :

Tabel 1. Klasifikasi Umur Responden

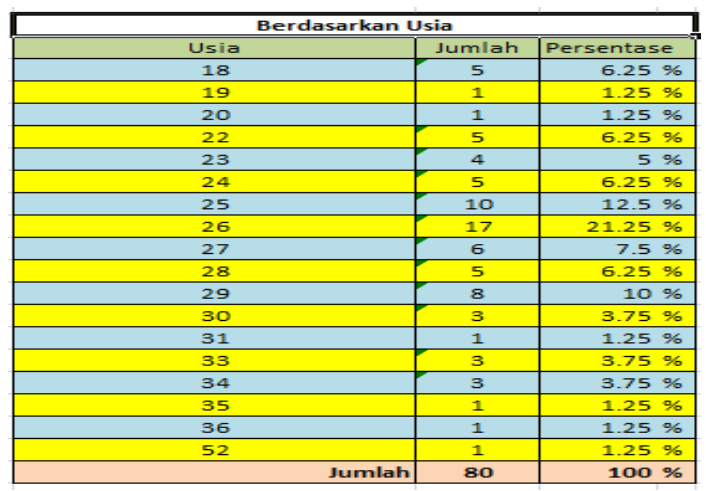

\section{Berdasarkan Usia}



Gambar 2. Pie Chart klasisifikasi Umur responden 
4.2.2. Kelompok Responden Berdasarkan Jenis Kelamin

Klasifikasi Jenis Kelamin (JK) responden berjumlah 80 orang tertera pada tabel berikut :

Tabel 2. Klasifikasi Jenis Kelamin Responden Berdasarkan Jenis Kelamin

\begin{tabular}{|c|c|c|c|}
\hline JK & Jumlah & Persentase & \\
\hline Pria & 44 & $\mathbf{5 5} \%$ \\
\hline Wanita & 36 & $45 \%$ \\
\hline & Jumlah & $\mathbf{8 0}$ & $\mathbf{1 0 0 \%}$ \\
\hline
\end{tabular}

\section{Berdasarkan Jenis Kelamin}

5544

Jumlah Persentase

Gambar 3. Pie Chart klasisifikasi Jenis Kelamin responden

4.2.3. Kelompok Responden Berdasarkan Pendidikan

Kelompok responden berjumlah 80 orang mempunyai tingkat pendidikan dari SMP hingga Strata 1. Penjelasannya adalah sebagai berikut:

Tabel 3. Klasifikasi Pendidikan Responden

\begin{tabular}{|c|c|c|}
\hline Berdasarkan Pendidikan & & \\
\hline Pendidikan & Jumlah & Persentase \\
\hline SMU & 26 & $32.5 \%$ \\
\hline Diploma 3 & 19 & $23.75 \%$ \\
\hline Strata 1 & 27 & $33.75 \%$ \\
\hline Strata 2 & 8 & $10 \%$ \\
\hline Jumlah & 80 & $100 \%$ \\
\hline
\end{tabular}

\section{Berdasarkan Pendidikan}



Gambar 4. Column Chart klasisifikasi Pendidikan responden
Kelompok responden berjumlah 80 orang mempunyai bidang pendidikan yang diklasifikasi khusus pada bidang Teknologi Informasi/ Sistem Informasi/ Manajemen Informasi, Sosial/ Ekonomi/ Akuntansi dan klasifikasi lainnya berada pada bidang Lainnya. Jumlahnya dapat ditampilkan sebagai berikut:

Tabel 4. Klasifikasi Bidang Studi Responden Berdasarkan Bidang Studi

Berdasarkan Bidang Studi
\begin{tabular}{|l|c|r|r|}
\hline \multicolumn{1}{|c|}{ Pendidikan } & Jumlah & Persentase & \\
\hline Akuntansi & 9 & $11.25 \%$ \\
\hline Ekonomi & 13 & $16.25 \%$ \\
\hline Elektro & 7 & $8.75 \%$ \\
\hline Hukum & 1 & $1.25 \%$ \\
\hline Komunikasi & 4 & $5 \%$ \\
\hline Manajemen Informatika & 9 & $11.25 \%$ \\
\hline Pendidikan & 1 & $1.25 \%$ \\
\hline Psikologi & 2 & $2.5 \%$ \\
\hline Sistem Informasi & 25 & $31.25 \%$ \\
\hline SMA & 2 & $2.5 \%$ \\
\hline Teknik Komputer & 1 & $1.25 \%$ \\
\hline Teknik Sipil & 2 & $2.5 \%$ \\
\hline TKJ & 4 & $5 \%$ \\
\hline \multicolumn{1}{|c|}{ Jumlah } & $\mathbf{8 0}$ & $\mathbf{1 0 0} \%$ \\
\hline
\end{tabular}

\section{Berdasarkan Bidang Studi}

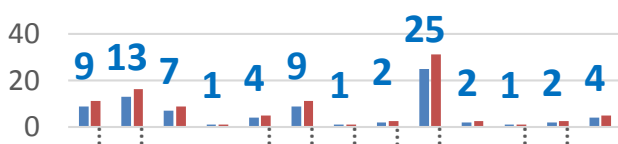

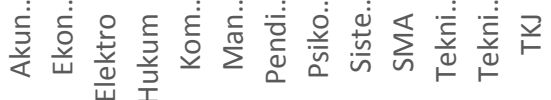

$$
\begin{aligned}
& \text { - Jumlah Persentase }
\end{aligned}
$$

Gambar 5. Column Chart klasisifikasi Bidang Studi responden

4.2.4. Kelompok Responden Berdasarkan Pekerjaan

Kelompok responden berjumlah 80 orang pekerjaan sebagai berikut:

Tabel 5. Klasifikasi Jenis Pekerjaan Responden Berdasarkan Pekerjaan

\begin{tabular}{|c|c|c|}
\hline Pekerjaan & Jumlah & Persentase \\
\hline BUMN & 10 & $12.5 \%$ \\
\hline Guru & 1 & $1.25 \%$ \\
\hline Mahasiswa & 22 & $27.5 \%$ \\
\hline Pegawai Perusahaan Swasta & 19 & $23.75 \%$ \\
\hline PNS & 13 & $16.25 \%$ \\
\hline Wiraswasta & 6 & $7.5 \%$ \\
\hline Wirausahaan & 9 & $11.25 \%$ \\
\hline Jumlah & 80 & $100 \%$ \\
\hline
\end{tabular}

4.2.4. Kelompok Responden Berdasarkan Bidang Studi 


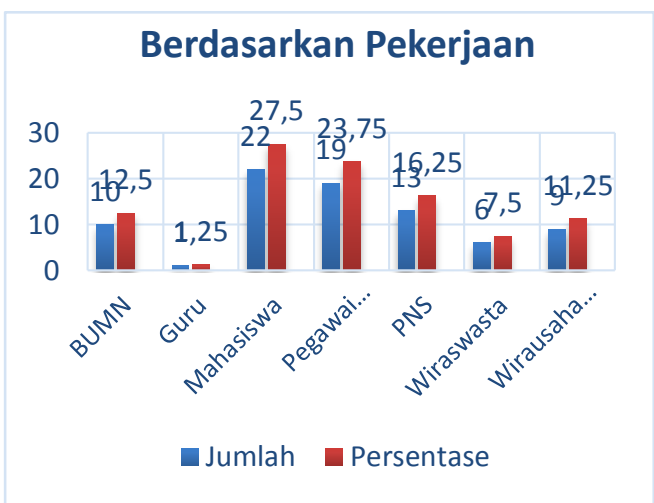

Gambar 6. Column Chart klasisifikasi Pekerjaan responden

\subsection{Deskripsi Kualitas Website}

\subsubsection{Dimensi 1}

Merupakan penilaian terhadap Ketersediaan, Kemudahan Pengaksesan, dan Keamanan. Dimana hal-hal yang ditanyakan adalah sebagai berikut:

1. Apakah Website ini mudah untuk diakses dan dinavigasi?

2. Apakah Website ini selalu ada, tersedia, dan mudah ditemukan?

3. Apakah Website ini memiliki keamanan yang memadai untuk melakukan transaksi?

\subsubsection{Dimensi 2}

Merupakan penilaian terhadap Kelengkapan Fasilitas Penunjang dan Kecepatan Pengaksesan. Dimana hal-hal yang ditanyakan adalah sebagai berikut:

1. Apakah Website ini memiliki fasilitas pencarian yang memadai?

2. Apakah Website ini memiliki tautan (links) yang valid dan beragam?

3. Apakah Website ini dapat dipersonalisasi sesuai dengan keinginan pengguna?

4. Apakah Website ini memiliki kecepatan yang memadai ketika dibuka?

5. Apakah Website ini memiliki fitur interaktif yang banyak dan beragam?

\subsubsection{Dimensi 3}

Merupakan penilaian terhadap Kualitas Informasi. Dimana hal-hal yang ditanyakan adalah sebagai berikut:

1. Apakah informasi yang tersedia dalam Website ini sangat berguna bagi anda?

2. Apakah informasi yang tersedia dalam Website ini lengkap atau komprehensif?

3. Apakah informasi yang tersedia dalam Website ini disajikan dengan jelas dan mudah dipahami?

4. Apakah informasi yang tersedia dalam Website ini ringkas namun padat?
5. Apakah informasi yang tersedia dalam Website ini akurat dan dapat dipercaya?

\subsubsection{Dimensi 4}

Merupakan penilaian terhadap Penunjang Kebutuhan Pelanggan. Dimana hal-hal yang ditanyakan adalah sebagai berikut:

1. Apakah dalam Website ini tersedia sumber atau kontak informasi yang bisa dihubungi (nomor telefon, alamat email, dan lain-lain ) ?

2. Apakah dalam Website ini tersedia informasi yang bersifat umum tentang organisasi atau perusahaan yang memiliki website ini (visi, misi, tujuan organisasi, struktur organisasi, dan lain-lain)?

3. Apakah dalam Website ini tersedia informasi tentang hak dan kewajiban pengguna?

4. Apakah dalam Website ini tersedia informasi tentang layanan yang dapat dimanfaatkan pelanggan/pengguna?

\subsubsection{Dimensi 5}

Merupakan penilaian terhadap Penunjang Kebutuhan Pelanggan. Dimana hal-hal yang ditanyakan adalah sebagai berikut:

1. Apakah tampilan Website ini tampak menarik (atraktif)?

2. Apakah tampilan Website ini tertata dengan rapi?

3. Apakah Website ini menggunakan ukuran font yang proporsional?

4. Apakah Website ini menggunakan tatawarna yang serasi?

5. Apakah Website ini menggunakan fasilitas multimedia dengan tepat dan proporsional?

\subsection{Hubungan Antara 5 Variabel Dimensi Kualitas Website Dengan Variabel Kepuasan}

Tabel 6. Tabel Descriptive Statistic: Regresi Linier Berganda pada 5 variabel Dimensi terhadap Kepuasan 


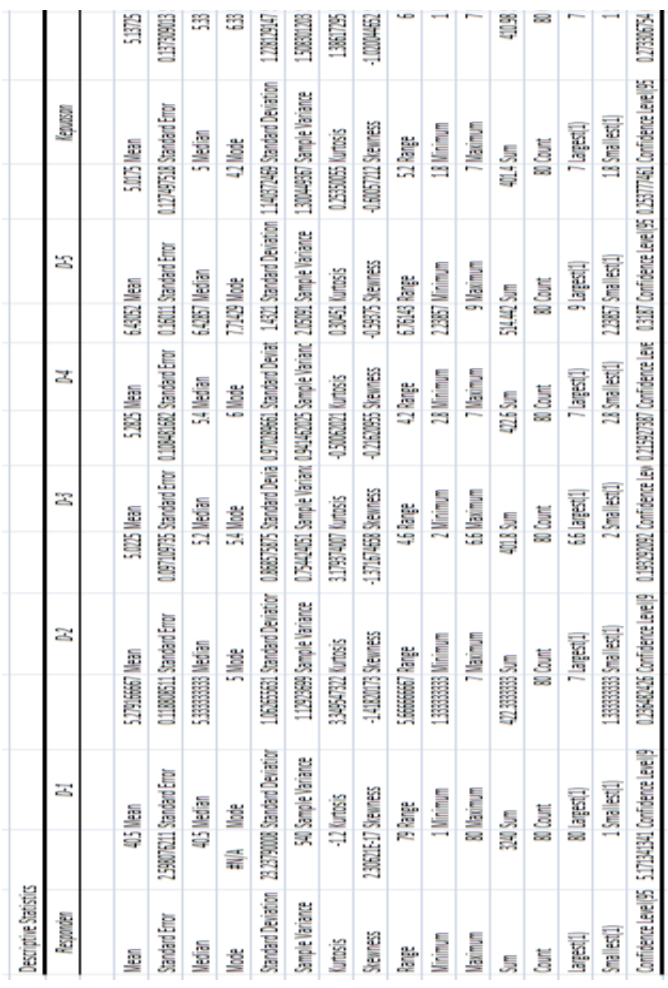

Tabel di atas menerangkan mean (rata-rata) data dari tiap variable yang digunakan di dalam regresi, standar deviasi untuk kesalahan regresi dan jumlah data yang digunakan.

Tabel 7. Tabel Correlations : Regresi Linier Berganda pada 5 variabel Dimensi terhadap Kepuasan

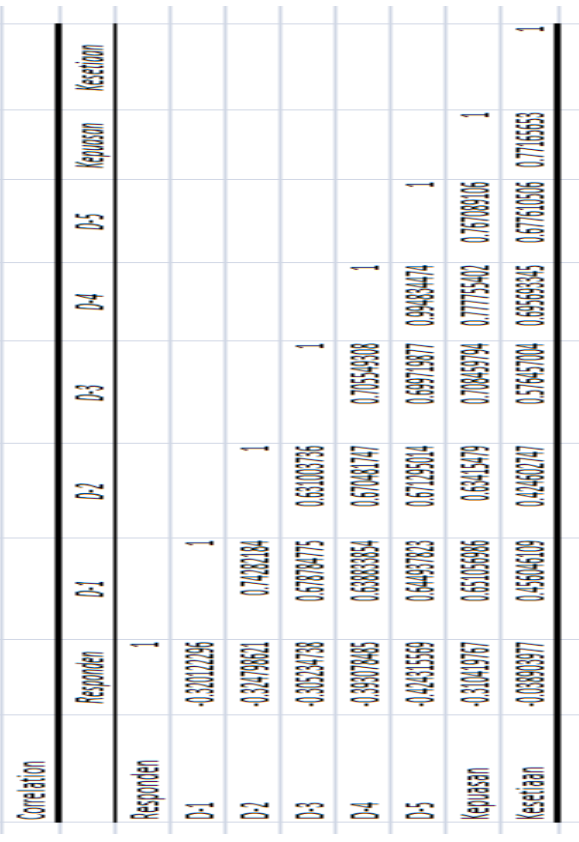

Korelasi diantara tiap variable memperlihatkan hubungan diantara kedua variable yang berkaitan. Pada Dimensi 1 (D1) dengan Kepuasan (K) berkorelasi dengan nilai 0,651. Pada Dimensi 2 (D2) dengan Kepuasan (K) dengan nilai 0,634. Pada Dimensi 3 (D3) dengan Kepuasan pada nilai 0,708. Pada Dimensi 4 (D4) dengan variable Kepuasan (K) pada nilai 0,777. Dan variabel Dimensi 5 (D5) dengan Kepuasan (K) pada nilai 0,767

Angka signifikasi menunjukkan, adanya jarak signifikansi (sig.) yang dekat diantara variabel dengan kepuasan. Nilai batasan signifikansi adalah 0,05 dan korelasi variabel D2 dengan variabel Keputusan melewati batasnya, yaitu 0,05 . Yang berarti bahwa jarak keduanya tidak signifikan. Sedangkan variabel lainnya berada di bawah nilai batas yang berarti hubungan diantara kedua variabel adalah signifikan.

Bagian ketiga adalah banyak data yang dianalisa, yaitu 80 data.

Tabel 8. Tabel Model Summary Regresision statistic pada 5 variabel Dimensi terhadap

Kepuasan

\begin{tabular}{l|r|}
\hline \multicolumn{2}{|l|}{ SUMMARY OUTPUT } \\
\hline \multicolumn{2}{|c|}{ Regression Statistics } \\
\hline Multiple R & 0.613592639 \\
\hline R Square & 0.376495927 \\
\hline Adjusted R Square & 0.315877475 \\
\hline Standard Error & 19.2204621 \\
\hline Observations & 80 \\
\hline
\end{tabular}

Tabel 9. Tabel ANOVA : Regresi Linier Berganda pada 5 variabel Dimensi terhadap Kepuasan

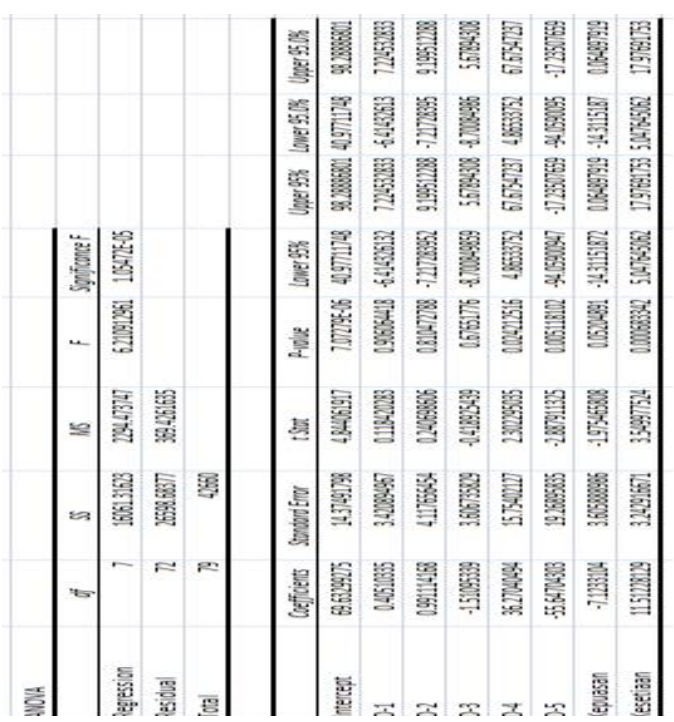


Pada ANOVA, nilai $\mathrm{F}$ menunjukkan angka 6,210 dan Significance F memperlihatkan signifikansi yang berada diatas batas 0,05 ; yaitu 1,054. Maka, regresi ini tidak layak dilakukan.

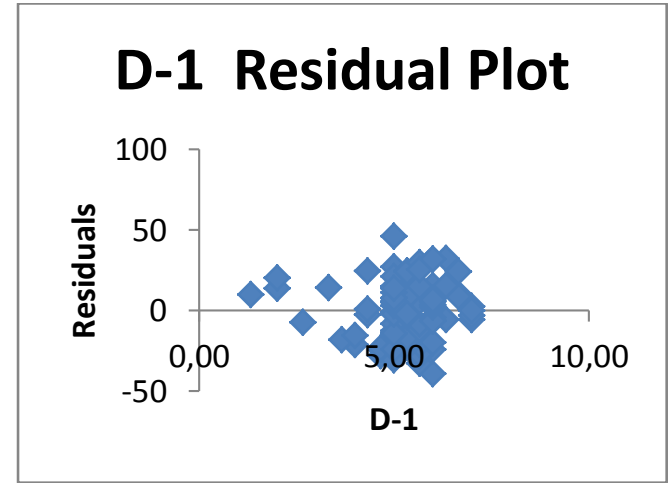

Gambar 7. Sebaran titik nilai Regresi data variabel D1 dan K

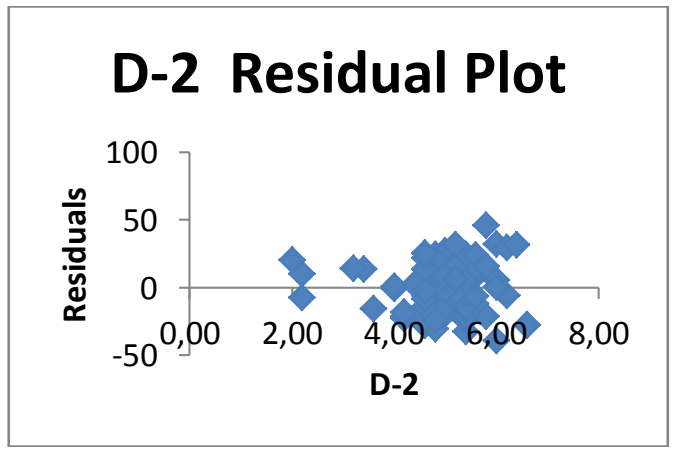

Gambar 8. Sebaran titik nilai Regresi data variabel D2 dan $\mathrm{K}$

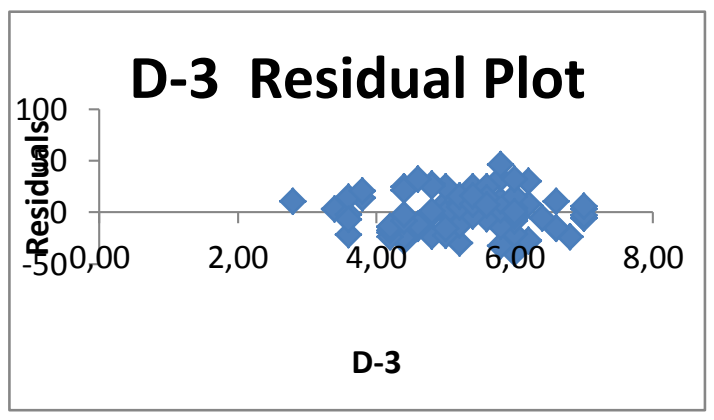

Gambar 9. Sebaran titik nilai Regresi datavariabel D3 dan $\mathrm{K}$

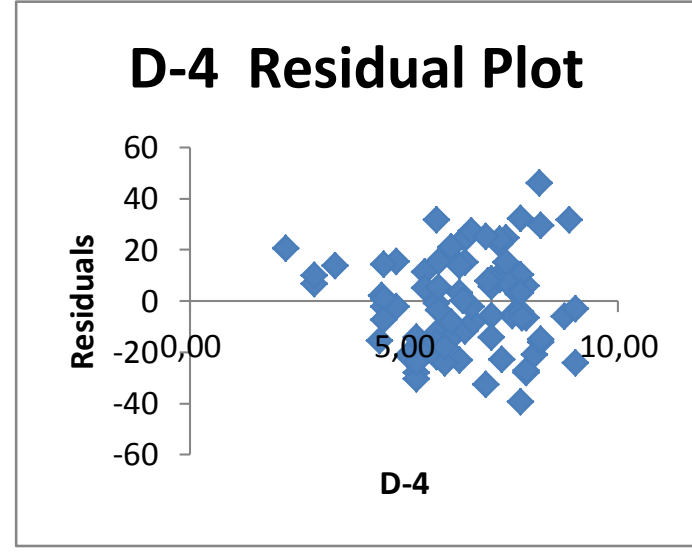

Gambar 10. Sebaran titik nilai Regresi data variabel D4 dan K

\section{D-5 Residual Plot}

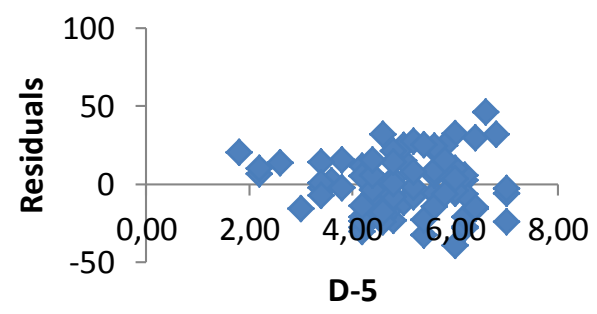

Gambar 11.Sebaran titik nilai Regresi data variabel D5 dan K

Gambar-gambar diatas menunjukkan tingkat penyebaran data yang ada. Gambar 1 merupakan penyebaran data pada variabel Dimensi 1 (D1) pada variabel Kepuasan (K), gambar ke-2 menggambarkan penyebaran variabel Dimensi 2 (D2) pada variabel Keputusan (K), gambar 3 untuk penyebaran D3, gambar 4 untuk penyebaran variabel D4 dan gambar 5 untuk menggambarkan penyebaran data di D5 pada variabel Keputusan (K).

\subsection{Hubungan Antara Kepuasan Dengan} Loyalitas

Berikut merupakan perhitungan hubungan antara variabel Kepuasan (K) dengan Loyalitas (L). Perhitungan ini dilakukan untuk mengetahui seberapa besar pengaruh variabel independent Kepuasan (K) terhadap variabel dependent Loyalitas. 
Tabel 10. Tabel Descriptive Statistic : Regresi Linier Sederhana pada variabel Kepuasan terhadap Loyalitas

\begin{tabular}{|l|r|}
\hline \multicolumn{2}{|c|}{ Regression Statistics } \\
\hline Multiple R & 0.771657 \\
\hline R Square & 0.595454 \\
\hline Adjusted R Square & 0.590267 \\
\hline Standard Error & 0.78613 \\
\hline Observations & 80 \\
\hline
\end{tabular}

Tabel 11. Tabel Correlations : Regresi Linier Sederhana pada variabel Kepuasan terhadap Loyalitas

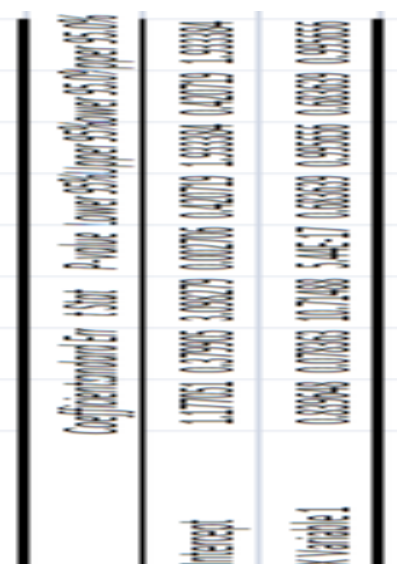

Tabel 12. Tabel ANOVA : Regresi Linier Sederhana pada variabel Kepuasan terhadap Loyalitas

\begin{tabular}{|c|c|c|c|c|c|}
\hline ANOVA & & & & & \\
\hline & $d f$ & SS & MS & $F$ & gnificance F \\
\hline Regression & \multicolumn{5}{|c|}{$170.95177 \quad 70.95177$ 114.8086 5.44E:-17 } \\
\hline Residual & \multicolumn{3}{|c|}{7848.20402} & & \\
\hline Total & \multicolumn{3}{|c|}{79119.1558} & & \\
\hline
\end{tabular}

Pada gambar tabel ANOVA, nilai $\mathrm{F}$ adalah 114,8086 dengan signifikansi sebesar 5,44. Ini berarti regresi yang dilakukan layak untuk dipakai.
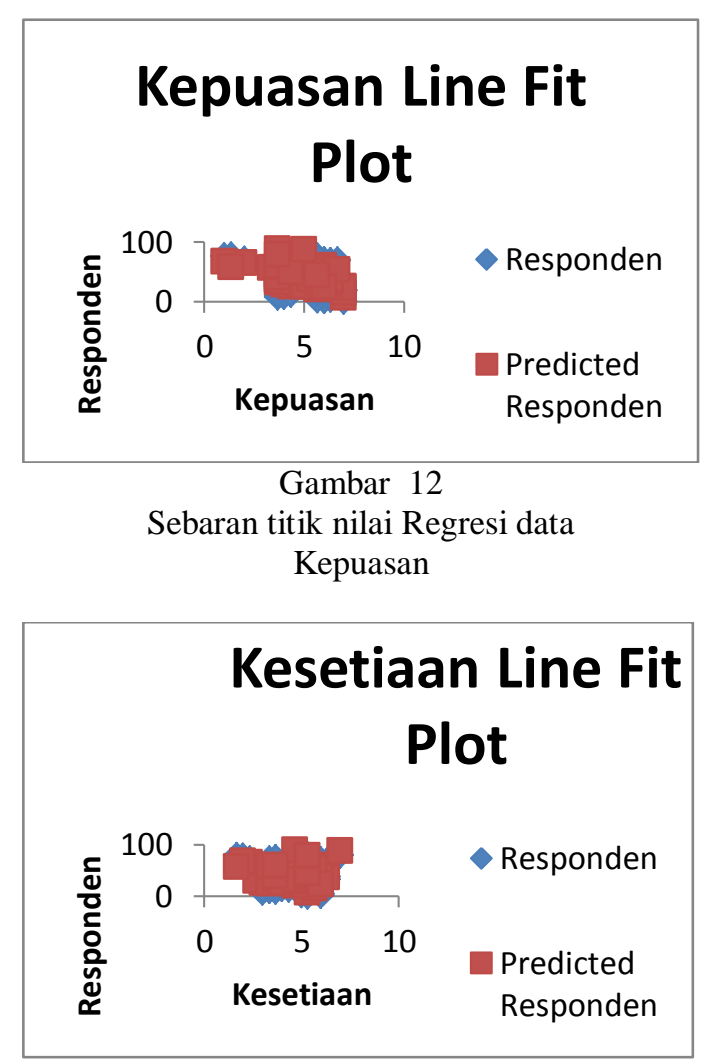

Gambar 13.

Sebaran titik nilai Regresi data kesetian

Dua gambar diatas menunjukkan tingkat penyebaran data yang ada. Gambar pertama merupakan gambaran peryebaran data yang diharapkan, untuk mencapai tujuan regresi terbaik. Kemudian, gambar kedua merupakan penyebaran data pada variabel kepuasan pada variabel kesetian..

\section{PENUTUP}

Kesimpulan yang dapat ditarik dari penelitian ini adalah bahwa pada kualitas website tersebut menampilkan hubungan 5 variabel Dimensi Kualitas Website yang mempengaruhi variabel Kepuasan pengguna website. Terlihat dari besarnya hubungan (korelasi) yang dimiliki tiap-tiap variabel Dimensi Kualitas Website terhadap variabel Kepuasan. Pada Dimensi 1 (D1) dengan Kepuasan (K) berkorelasi dengan nilai 0,651. Pada Dimensi 2 (D2) dengan Kepuasan (K) dengan nilai 0,634. Pada Dimensi 3 (D3) dengan Kepuasan pada nilai 0,708. Pada Dimensi 4 (D4) dengan variable Kepuasan (K) pada nilai 0,777. Dan variabel Dimensi 5 (D5) 
dengan Kepuasan (K) pada nilai 0,767. Nilai signifikansi yang ditampilkan menunjukkan bahwa hubungan diantara kedua variabel perhitungan pada tiap dimensi memiliki signifikansi yang hampir kesemuanya cukup baik, sehingga regresi ini layak untuk dilakukan. Dan pengaruh 5 variabel dimensi tersebut berpengaruh pada variabel kepuasan sebesar 72, Pada ANOVA, nilai F menunjukkan angka 6,210 dan Significance F memperlihatkan signifikansi yang berada diatas batas 0,05 ; yaitu 1,054. Maka, regresi ini tidak layak dilakukan.. dan nilai yang didapatkan memperlihatkan pengaruh 5 variabel Dimensi Kepuasan Website terhadap variabel Kepuasan.

Kemudian, pada perhitungan pengaruh variabel Kepuasan terhadap variabel Loyalitas pelanggan maka akan didapatkan Pada gambar tabel ANOVA, nilai $F$ adalah 114,8086 dengan signifikansi sebesar 5,44. Ini berarti regresi yang dilakukan layak untuk dipakai. Hal itu pula memperlihatkan bahwa pengaruh yang dimiliki variabel kepuasan pada regresi ini dapat memberikan penilaian pengaruh loyalitas pengguna website www.Biznetnetworks.com Ini berarti regresi yang dilakukan layak untuk dipakai.

Dengan tingginya nilai pengaruh yang dimiliki oleh variabel-variabel perhitungan, baik pada perhitungan regresi linier berganda maupun perhitungan regresi linier sederhana. Hal tersebut memberikan penilaian seberapa baik kualitas dari penyampaian produk menggunakan website berpengaruh dari loyalitas pengguna website. Hasil penelitian yang didapatkan dapat dijadikan tolak ukur pengambilan keputusan terhadap ke-efektifan penggunaan website sebagai media pemasaran produk dan optimalisasi penggunannya.

\section{DAFTAR PUSTAKA}

[1] Wijaya, Toni: "Praktis dan Simpel Cepat Menguasai SPSS 20", Penerbit Atma Jaya, Mei 2012.

[2] Sarwono, Jonathan: "Mengenal SPSS Statistic 20",Penerbit Elex Media Komputindo 2012

[3] www.Biznetnetworks.com
[4] Stuart J. Barnes and Richard Vidgen :" Measuring Web site quality improvements: a case study of the forum on strategic management knowledge exchange." Industrial Management \& Data Systems . 103/5 [2003] 297-309.

[5] Sidonia Otilia Cernea, Janetta Sîrbu, Nicolae Mărginean.:" DETERMINATION OF USERS SATISFACTION LEVEL REGARDING THE QUALITY OF E-SERVICES

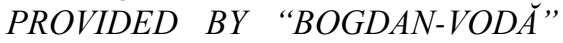
UNIVERSITY”. Annales Universitatis Apulensis Series Oeconomica, 11(2), 2009.

[6] MONIDEEPA TARAFDAR, JIE ZHANG." Determinants of Reach and Loyalty A Study of Website Performance and Implications for Website Design". Journal of Computer Information Systems Winter 20072008

[7] Zhilin Yang, Shaohan Cai, Zheng Zhou, Nan Zhou." Development and validation of an instrument to measure user perceived service quality of information presenting Web portals". Information \& Management 42 (2005) 575-589

[8] Abdul R Saliman, SH, MM, dkk, "Hukum Bisnis Untuk Perusahaan (Teori dan Contoh Kasus)", Kencana Renada Media Group, Jakarta 2005. Hal. 100, dikutip dari : http://repository.usu.ac.id 